\title{
POLICY REPORT ON
}

\section{UNHCR's Community Technology Access Program: Best Practices AND LESSONS LEARNED}

\author{
JessicA Anderson
}

\begin{abstract}
This report gives an overview of UNHCR's Community Technology Access (CTA) program, which aims to improve education and livelihood opportunities for displaced populations via technology. The paper analyzes the key findings of a comprehensive external evaluation of the program conducted in 2012. According to the evaluation, the areas of greatest positive impact for people of concern were in the enjoyment of basic rights to freedom of expression and information, in building relationships with the host community, and social networking. However, access to technology alone is not sufficient to achieve the goals of quality education and self-reliance. Therefore, the evaluation recommends developing strategic, contextualized education and livelihood content and tools in order to achieve the desired goals of learning, skills, and access to employment, as well as a reassessment of CTAs' potential for operational and fiscal autonomy in different countries.
\end{abstract}

\section{Résumé}

Ce rapport donne un aperçu du programme d'Accès Communautaire aux Technologies (CTA) de l'Agence des Nations Unies pour les Réfugiés (UNHCR), qui vise, à travers la technologie, à améliorer l'éducation et les opportunités de moyens de subsistance des populations déplacées. Cet article analyse les principaux résultats d'une évaluation externe complète du programme effectuée en 2012. Selon cette évaluation, les impacts positifs les plus importants de ce programme se situaient au niveau de la jouissance des droits fondamentaux à la liberté d'expression et à l'accès à l'information, ainsi qu'au niveau de l'intégration dans la communauté d'accueil et du réseautage social. Toutefois, l'accès à la technologie n'est pas suffisant seul pour atteindre les objectifs d'éducation et d'autonomie. Cette évaluation recommande donc le développement stratégique et contextuel de contenus et d'outils en matière d'éducation et de moyens de subsistance, dans le but d'atteindre les objectifs d'apprentissage, de compétence, d'accès à l'emploi, et de réévaluer les possibilités d'autonomie opérationnelle et financière des Centre Communautaires d'Accès à la Technologie de divers pays.

\section{Goals}

As an integral part of its protection mandate, UNHCR aims to empower refugees, internally displaced persons, and others "of concern"1 and to enhance their overall well-being, along with their education and livelihood opportunities. Indeed, two of the Global Strategic Priorities for UNHCR in 2012-2013 are promoting "human potential through education, training, livelihoods support and income generation" and durable solutions. ${ }^{2}$ Promoting self-reliance among persons of concern can play an important role in preparing them for durable solutions, whether by facilitating employability for local integration, by developing the skills necessary to continue education upon resettlement, or by improving their ability to contribute to peace building and local development upon return to their country of 
origin. ${ }^{3}$ UNHCR understands self-reliance as the social and economic ability of an individual, household, or community to meet basic needs (including protection, food, water, shelter, personal safety, health, and education) in a sustainable manner and with dignity. Self-reliance, as a program goal, refers to developing and strengthening livelihoods of persons of concern (PoCs), and reducing their vulnerability and long-term reliance on humanitarian or external assistance. By becoming self-reliant, displaced populations lead active and productive lives and are able to weave strong social, economic, and cultural ties with their host communities. UNHCR is committed to protecting the skills and productive assets that displaced people carry with them, to building the capacities they might need in a new environment, and to broadening opportunities in this new environment. ${ }^{4}$

\section{CTA Program Background}

In line with these broader imperatives, UNHCR launched the Community Technology Access (CTA) program in 2009. The main goals of the CTAs were to "enhance empowerment, self-reliance and employability of refugees and other UNHCR persons of concern through access to education, vocational training and livelihoods via technology." ${ }^{5}$ The CTA program provides centres that allow persons of concern and their host communities to have access to computer technology and the Internet for the purposes of basic information technology (IT) classes; livelihoods, vocational, and life skills training; distance learning; language courses; promoting entrepreneurship and employability; access to information; and/or social networking. This report gives an overview of the CTA program and analyzes the key findings of a comprehensive external evaluation of the program conducted in $2012 .{ }^{6}$

The CTA program is overseen by the Livelihoods Unit within the Operations Solutions and Transition Section within the Division of Program Support and Management (DPSM) at UNHCR headquarters, in close collaboration with the Education Unit within the Division of International Protection. ${ }^{7}$ At the field level, individual CTAs are usually run by NGO implementing partners. Other key partners include Microsoft and Hewlett-Packard, who provide technical assistance, software, and equipment, as well as financial support. There are currently fifty-six CTAs in place, spread throughout all five of the regions where UNHCR works (Africa, the Americas, Asia and the Pacific, Europe, and the Middle East and North Africa). According to DPSM, approximately 20,000 people benefit from the global CTA program each year. ${ }^{8}$ CTAs are located in urban, semiurban, or rural/camp contexts and are implemented over a five-year timeline, with the goal being that they become fiscally self-sufficient by the end of this period. ${ }^{9}$

\section{Education, Livelihoods, and Technology for Refugees}

In examining the results of the 2012 CTA evaluation, it is helpful to contextualize the CTA program within broader research on how to best promote livelihoods for refugee populations through education and training. Interest in promoting self-reliance for refugees has intensified since 2003, which saw UNHCR establish its Refugee Livelihoods Project ${ }^{10}$ and the publication of Jeff Crisp's article on protracted displacement. ${ }^{11}$ It became clear that a "hand-out" humanitarian assistance approach ${ }^{12}$ was not promoting selfreliance for refugees, particularly in protracted situations. ${ }^{13}$ On the other hand, focusing on self-reliance acknowledges refugees' agency and their potential to benefit host communities. ${ }^{14}$ While barriers to livelihoods normally revolve around legal status, restricted mobility, and negative perceptions by the host community, UNHCR has recently emphasized the potential of innovation and private-sector engagement to circumvent these obstacles. ${ }^{15}$

As refugees assess their own prospects for self-reliance, they often use education as a future-oriented livelihoods strategy. ${ }^{16}$ However, determining which types of education and skills development will actually improve self-reliance is difficult, given the extreme uncertainty of refugees' futures and their current precarious legal status. ${ }^{17}$ For this reason, it is crucial to examine precisely which skills and programs will realistically improve refugees' self-reliance in their current situations and immediate future, rather than envisioning durable solutions that may be years away. ${ }^{18}$ Technical and vocational education programs should be tailored to the demands of the local labour market or the market in the country of origin, if return is imminent. ${ }^{19}$ Otherwise, the investment in education will be lost and the frustrated expectations of youth can lead to further instability. $^{20}$ Walker, Millar Wood, and Allemano argue that donors must be prepared to support participants through the whole process of "school to skills to work,"21 rather than merely providing one-off programs or a training certificate. $^{22}$ Integrating all of these activities, along with life skills training, into comprehensive education programs is especially important for individuals whose education has been disrupted by conflict and displacement and who therefore require accelerated programs. ${ }^{23}$

The strategy of using access to technology to advance refugee education and livelihoods has received increased attention since the early 2000 s. $^{24}$ For example, using technology to provide distance learning opportunities for refugees has been the focus of various projects, including 
interactive radio instruction programs and mobile phone literacy games. ${ }^{25}$ More recently, Jesuit Refugee Services and the Borderless Higher Education for Refugees project are working to provide tertiary education and teacher training in camps through online learning. ${ }^{26}$ Access to technology can also be used to engage refugees in virtual work and data outsourcing for overseas companies, thereby bypassing labour restrictions in host countries, as has been piloted in Dadaab. ${ }^{27}$ While these projects and others have had positive results, one common pitfall in implementing Information and Communications Technology (ICT) initiatives is the tendency to "dump hardware in schools [and] hope for magic to happen" and to "think about [...] content only after you have rolled out your hardware." 28 UNHCR's experience with its CTA program has highlighted both the positive education, livelihoods, and social networking potential of ICT initiatives, and the risks associated with attributing inherently transformative qualities to technology.

\section{Evaluation Methodology}

In April 2012, UNHCR decided to commission an external evaluation of the CTA program, given its rapid expansion over the course of three years. The evaluation was commissioned as an impact assessment ${ }^{29}$ and does qualitatively analyze positive and negative outcomes, ${ }^{30}$ although it lacks the rigorous quantitative methods necessary to study causal mechanisms, as would have been required for a formal outcome evaluation. ${ }^{31}$ Thus, one could argue that this is a mixed evaluation, which also uses a more formative approach, in that its findings can serve to optimize CTAs' future impact on quality of education and access to livelihoods. ${ }^{32}$

The evaluation focused on five countries (Armenia, Georgia, Kenya, Rwanda, and Yemen) and took place over a period of three months. These sites were selected based on the following criteria: (1) program implementation had been ongoing for at least twelve months; (2) representation of both urban and camp CTAs; (3) representation of locations with both formal and informal education systems; and (4) users with different socioeconomic and education backgrounds. ${ }^{33}$ While the evaluation's findings can be taken as general best practices and lessons learned for other CTAs, these findings will not be fully generalizable and will have to be adapted to the contexts of other CTA sites. The evaluation included desk reviews, field visits to CTA centres in four of the countries (travel to Yemen was hampered by the security situation), and interviews with CTA program "graduates," current participants, non-beneficiaries, implementing partners, course instructors, and key UNHCR staff in the field and in Geneva. When sampling participants from refugee and local host populations, efforts were made to include a balanced representation by gender, disability, etc. $^{34}$ Standardized surveys/questionnaires, guided interview protocols, and guided focus group protocols were used in the various sites. ${ }^{35}$ The evaluation consultants conducted fifteen focus groups, which included a total of 181 CTA beneficiaries, forty-nine interviews with IPs and UNHCR staff, and an unspecified number of semi-structured interviews with CTA participants. ${ }^{36}$ The evaluation highlighted several positive outcomes of the CTA program, which are outlined below. ${ }^{37}$

\section{Positive Outcomes of CTA Programs: Intended and Unintended \\ Human Rights}

Firstly, CTAs have improved the ability of many persons of concern to UNHCR to enjoy key human rights as set out in international legal instruments, including the right to freedom of expression and "freedom to seek, receive and impart information and ideas of all kinds, regardless of frontiers... through any other media of his choice." 38 Indeed, CTAs allow persons of concern to access information without hindrance, both for its own sake and to improve their ability to make informed and independent decisions. ${ }^{39} \mathrm{~A}$ focus group participant in Georgia explained,

This access and these computers play a really big role in our lives. Our society is so remote and the community center and having a place to come to helps us not be afraid, helps us to know things. People here never believed we would ever be connected to the outside world. ${ }^{40}$

In addition, persons of concern can use CTAs to learn about the situation in their country of origin for the purposes of a possible repatriation. As one CTA user from Argentina stated, "I cannot expect a local TV channel here to show the crisis in my country. But with the computer I can be informed. All I have to do is type the key words and read." 41 Furthermore, CTAs have expanded the range of educational options available to refugees, particularly tertiary education, and thus promoted the progressive realization of the right to education, as foreseen in the International Covenant on Economic, Social and Cultural Rights. ${ }^{42}$

\section{Self-Reliance}

Although challenges have arisen in systematically improving self-reliance and employment among refugees through the use of CTAs, specific contexts and individuals have seen success in this area. For example, one female CTA participant in Georgia used her new IT skills to advertise her home on a government website as a guesthouse for tourists. ${ }^{43}$ Other participants in Georgia were able to use the IT certificates they received upon completion of CTA courses to 
obtain jobs as secretaries. A CTA participant in Argentina stated, "I use the computer to do my homework...I also send CVs to find a job. I received three answers for interviews last month."44 Iraqi refugees in Armenia used CTAs to join online advertising sites to publicize their small businesses. ${ }^{45}$ Another example from Uganda highlights the experience of a Congolese refugee setting up a successful multimedia business through the CTA centre. ${ }^{46}$ While these examples demonstrate that certain individuals have experienced positive self-reliance outcomes in various CTA locations, overall results are more varied. In Kakuma camp in Kenya, approximately 90 percent of CTA graduates have been employed by NGOs and other organizations. ${ }^{47}$ However, in Georgia, the evaluation consultants noted that most CTAs provided no programming beyond basic IT skills and did not collect data on employment outcomes of these graduates. Unfortunately, the evaluation report provides mainly anecdotal evidence about overall livelihoods outcomes for CTA graduates, and so it is difficult to objectively analyze the causes of disparities between programs.

\section{Education}

In its 2012-2016 Education Strategy, UNHCR lists as one of its strategic approaches the "innovative use of technology [to] expand education opportunities," and names collaboration with the CTA program and the use of Skype in the classroom as two ways to accomplish this. ${ }^{48}$ Indeed, CTAs provide an ideal forum for augmenting both formal and informal education opportunities and distance learning, including specific courses for school children, adult learners, and single mothers, among others. ${ }^{49}$ For example, primary school children in Kiziba camp in Rwanda were able to participate in Skype chat sessions with students in the United States, thus broadening horizons for both groups of children. The Kiziba CTA also provided access to a distance-learning math and science simulation program. ${ }^{50}$ In Yemen, some CTA participants accessed English language training through software developed by the implementing partner. Finally, CTAs can also be used to develop important life skills, such as human rights awareness, reproductive health knowledge, or the prevention of sexual and genderbased violence. However, the evaluation notes that the education potential of CTAs is being severely underutilized, particularly in Georgia, Armenia, and Kenya, where the consultants were unable to find evidence of any systematic education or life skills programming beyond basic IT skills courses. ${ }^{51}$

\section{Age, Gender, and Diversity Mainstreaming}

UNHCR's 2011 Age, Gender and Diversity Policy calls for the mainstreaming of a programming approach ensuring that all persons of concern enjoy their rights on an equal footing and are able to participate in decisions that affect them. ${ }^{52}$ In terms of the CTA, this means designing and implementing the program in such a way that it takes into account the unique needs of different individuals and groups, especially women and girls, youth, persons with disabilities, and other marginalized groups. CTAs in many countries have made important steps in this regard, including by providing an education opportunity that is accessible to women and viewed as culturally acceptable for them. One CTA participant in Georgia noted:

This CTA helps us as women become more than just slaves, which we are in our homes. It helps us show men that we can learn something they haven't bothered with that is critical for our children and their education and their lives. The CTA gives us two hours of freedom a day when we are able to take classes here; freedom we would not otherwise have. ${ }^{53}$

Female graduates can often pursue further independent learning in various areas, such as microenterprise skills. CTAs also provide users with the opportunity to research problems that they identify within their communities and to take ownership of possible solutions. As one Kenyan CTA participant stated,

[I use the CTA to] research specific problems affecting my immediate community in order to work on a plan to solve the problem-for example conducting research on why the rate of the girls' enrolment in schools is very low in our community. ${ }^{54}$

Although efforts are made to include persons with disabilities in CTA programs, including by making centres accessible, obstacles persisted, such as poor furniture setup in the centres or poor mobility conditions in the rest of the camp. ${ }^{55}$ The most positive outcome was experienced in Yemen, where 27 percent of participants in one CTA were persons with disabilities. This success was due in part to the fact that the IP was an NGO that worked specifically with persons with disabilities. ${ }^{56}$ It was noted that the participation of people with disabilities in this program had significantly increased the community's acceptance of them as a result of interactions at the centre. ${ }^{57}$

\section{Relationships with the Host Community}

The CTA program has successfully promoted UNHCR's policy to ensure that its projects assist both persons of concern and the host community. Indeed, the 2009 Policy on Refugee Protection and Solutions in Urban Areas states that UNHCR will 
encourage refugees and their local hosts to interact in a positive manner. To attain this objective, UNHCR will endeavour to combat discrimination and xenophobia and will ensure that the services it provides to urban refugees bring benefits to other citydwellers, especially the neediest sections of the population and those who live in closest proximity to refugees. ${ }^{58}$

This principle also applies in camp settings, although in practice, the location of camps sometimes represents an obstacle to including local communities in CTA activities. Nevertheless, the fact that generally both persons of concern and local residents have access to CTA programming facilitates interaction and exchange between these groups, thus improving intercommunal relationships, peaceful coexistence, peace building, and security. During focus groups in Georgia, AIR researchers recorded that:

[participants] said that locals from neighboring villages and towns would be in the classes and they started making friends. Some of the locals also gave work to some of the men to tend their land. They...mentioned that CTA brought people together and gave locals and IDPs an opportunity to know each other and behave as neighbors. These kinds of activities, several said, need to continue, as it isn't "just an idea" to have locals and IDPs working and doing activities together; "it’s a need."59

This type of interaction may promote greater openness to local integration on the part of the population and authorities, as well as ensuring that UNHCR's presence is viewed as contributing to local development.

\section{Social Networking}

Moreover, CTAs have played an important role in family communication and even reunification, in particular when persons of concern have been able to use social networking sites to track family members lost during displacement or to maintain connection with relatives who had been resettled abroad. The use of Skype, email, and Facebook allows persons of concern to communicate across borders even when telephone and postal services are unavailable. ${ }^{60}$ This somewhat unexpected benefit of CTAs should not be underestimated in its positive impact on refugees' well-being. Indeed, previous research in Kakuma camp showed that communication with family was the top reason motivating refugees to access the Internet. ${ }^{61}$ Furthermore, in other contexts, access to technology has enabled refugees to improve their livelihoods by connecting with family members and the diaspora community and receiving remittances from them, which in turn often allow persons of concern to pursue further education and training. ${ }^{62}$

\section{Challenges, Lessons Learned, and Recommendations}

While highlighting positive impacts of the CTA, the evaluation also noted several obstacles that were preventing the program from reaching its full potential.

\section{Education and Livelihoods Impact}

The main limitation revealed by the evaluation was that CTAs often experienced difficulties in providing courses beyond basic IT skills or in creating a tangible difference in the employment outcomes of graduates. For example, few CTAs in the countries evaluated had actually been able to offer distance learning courses and many of the school teachers interviewed said they had not used the CTAs for the development of lesson plans. Furthermore, in certain contexts, refugees have limited or no access to the labour market, due to legal provisions, remote location, or general economic conditions. Even in situations where persons of concern have the right to work, basic IT skills may not be enough to seek sustainable employment. Indeed, the set-up of a CTA was rarely accompanied by a labour market assessment to determine what type of livelihoods programming would be most useful. ${ }^{63}$ For example, one NGO staff member in Georgia observed that:

IDPs think that if they take a course to learn how to use a computer, and they receive the certificate that this will mean they get an automatic job. Then when this doesn't happen, there has been lots of disappointment and frustration. There is a value in providing free access to computers for IDPs and refugees, but there needs to be support and reflection in how to use the basic IT skills. ${ }^{64}$

Therefore, the evaluation recommends strategic mapping of local labour market and income-generating opportunities and the tailoring of CTA programming to offer the most relevant skills training for each particular situation. Furthermore, greater synergies could be promoted between CTAs both within and across countries, such as by creating forums for CTA teachers to share experiences and lesson plans. ${ }^{65}$ While numerous researchers ${ }^{66}$ have advocated for labour market mapping when designing technical and vocational education, it is clear that the CTA program has not yet fully implemented this strategy, and so repeated recommendations are necessary. In addition, one way to improve CTAs' livelihoods impact might be to build on current momentum towards innovation, in particular by implementing the Humanitarian Innovation Project's recommendation of Refugee Innovation Centres. These centres are envisioned as "a physical space within which refugees could receive access to microcredit, vocational training, mentorship, support with social innovation, business 
development, and the incubation of innovative ideas" 67 and it could be fitting to incorporate this type of programming into pre-existing CTAs. Regarding education, two key strategies advocated by ICT in education experts include prioritizing the use of ICT for teacher training and professional development, as well as offering distance learning opportunities to students. ${ }^{68}$

\section{Gender Equality}

Despite UNHCR's efforts to ensure equal participation, in many settings, such as Kakuma refugee camp, male participants far outnumber female participants. For example, among the Somali and Sudanese refugee communities in Kakuma, women and girls have significant household responsibilities, are expected to focus on marriage rather than education as they grow older, or have not completed primary school, which is required for enrolment in a CTA course. In these contexts, UNHCR and its partners need to conduct increased outreach to include women and girls and to offer classes for women only, taught by female instructors, wherever necessary, such as is done in the centre in Jalalabad, Afghanistan. ${ }^{69}$

\section{Technical Problems}

Another challenge that seriously hampered the functioning of many CTAs was technical shortcomings. During the start-up phase, many field offices experienced delays in receiving necessary materials, such as computers and software. In addition, when maintenance and repairs were needed for computers, internet connectivity, complex software, or solar panels, CTA functioning could be affected for long periods because of a lack of expertise among local technology companies. For example, when solar panels required repairs, CTAs were forced to run on generator power, thus significantly increasing costs. ${ }^{70}$

In order to ensure consistency and the fulfillment of program commitments to persons of concern, the evaluation recommends that procurement and maintenance be decentralized. Ideally, if computers and internet service are purchased locally rather than delivered via UNHCR headquarters, there would be fewer delays caused by transportation and customs issues. In addition, IT companies in the country would be familiar with the equipment and would be able to provide timely troubleshooting and support. ${ }^{71}$ Furthermore, this approach would allow UNHCR to support the domestic economy in the country of operation thus promoting its policy of positively contributing to local development. However, reliance on in-kind donations from corporate partners and limited or nonexistent local alternatives restrict the feasibility of decentralized procurement and maintenance at the current time.

\section{Operational and Fiscal Autonomy}

The stated goal for CTAs is that they will become independent from UNHCR headquarters and donors' support from the second year onward (being integrated into the operational budget of the field office) and then fully fiscally sustainable, preferably five years after start-up. ${ }^{72}$ Ideally, this means that they would be handed over to the ownership of entrepreneurs from refugee or host communities and would be able to cover their own costs. Although small user fees have been implemented in some CTA programs, such as in Yemen, many persons of concern would have difficulty paying any fee for CTA use, especially refugees in remote camps who are not employed as incentive workers. ${ }^{73}$ Therefore, such income-generating strategies must be tailored to the specific capacities of each population of CTA users. In addition, the evaluation recommends that UNHCR focus on alternative approaches for reducing operational costs (i.e. by reducing energy input and decentralizing service provision) and promoting different income-generating options (i.e. formatting and printing documents for NGOs).

\section{Conclusion}

Overall, the evaluation concluded that while UNHCR has been largely successful in providing access to technology through CTAs, this access alone is not enough to achieve significant improvements in education quality or livelihoods opportunities. Rather, if substantial impact is to be realized in all CTA centres, expertise and strategic planning at various levels are required to ensure that the content of CTA programming fits each specific context and effectively meets the needs of persons of concern. To this end, it is crucial to have continuous "buy-in" at the field level and an experienced implementing partner that can support UNHCR staff in identifying the resources required and available to bridge gaps in targeted content preparation and program delivery, based on market and socio-economic assessments, through local or regional solutions. ${ }^{74}$ Nevertheless, the fundamental value of basic IT literacy and access to information and social networking, which is already being provided by CTAs around the world, should not be underestimated. Rather, the concrete recommendations spelled out in this evaluation will only strengthen the ability of UNHCR to build on these accomplishments and to use both new and existing CTAs to their fullest potential in empowering persons of concern. UNHCR's Livelihoods Unit is currently developing a new CTA strategy, which is still in its early phases. Some preliminary ideas for change include: virtualizing services (making them available online); alternative approaches for running CTAs (including renting time at existing Internet cafes and/or privatizing centres); building capacity for training course creation at the local level; increasing on-site learning assistance; 
and engaging with education content marketplaces. ${ }^{75}$ This new CTA strategy, along with UNHCR's increased focus on using innovation and technology to benefit persons of concern, indicate bright prospects for CTAs. ${ }^{76}$

\section{Notes}

1. "Persons of concern" is the term used by UNHCR to refer to the categories of persons for whom UNHCR has responsibility under its mandate, namely refugees, asylum seekers, returnees, internally displaced persons, and stateless persons. UN High Commissioner for Refugees, Self-Study Module 1: An Introduction to International Protection. Protecting Persons of Concern to UNHCR, 1 August 2005, 83, http://www.refworld.org/docid/4214cb4f2.html.

2. "2012-2013 Global Strategic Priorities," Executive Committee of the High Commissioner's Program, 53rd Standing Committee, 21 February 2012, EC/63/SC/ CRP.7, accessed 29 August 2012, http://www.unhcr org/cgi-bin/texis/vtx/home/opendocPDFViewer html? docid $=4$ f6215e79\&query $=\mathrm{a} \% 20$ guide $\% 20$ to $\% 20$ resettlement\%20and\%20integration.

3. "UNHCR and Self-Reliance," UNHCR website, accessed August 29, 2012, http://www.unhcr.org/pages/4ad2e7d26 .html.

4. "Livelihood Programming in UNHCR: Operational Guidelines," 2012, http://www.refworld.org/docid/512611392 .html; communication with UNHCR Livelihoods Unit staff, July 17, 2013.

5. UNHCR Division of Operational Services, "Provision of Education and Livelihoods through Technology and Connectivity, Community Technology Access (CTA)" (April 2009), 5, see American Institutes for Research (AIR), “The Current State of UNHCR's Community Technology Access Program," Annex A: References section.

6. The author of this report was not personally involved in conducting the CTA evaluation. The aim of this paper is to present the evaluation findings, lessons learned, and next steps for the CTA program.

7. American Institutes for Research (AIR), "The Current State of UNHCR's Community Technology Access Program” (July 2012), 1.

8. Ibid., 17.

9. Ibid.; Division of Operational Services, UNHCR, "Project Proposal for the Provision of Education and Livelihoods through Technology and Connectivity" (April 2009), contained in AIR, "The Current State of UNHCR's CTA Program," Annex A: References Section.

10. Cindy Horst, "Refugee Livelihoods: Continuity and Transformations," Refugee Survey Quarterly 25, no. 2 (2006), $6-22$.

11. Jeff Crisp, "No Solutions in Sight: The Problem of Protracted Refugee Situations in Africa," UNHCR New Issues in Refugee Research 75 (2003), http://www.unhcr.org/3e2d66c34 .html.
12. Horst, "Refugee Livelihoods."

13. Alexander Betts, Louise Bloom, and Naohiko Omata, "Humanitarian Innovation and Refugee Protection," Refugee Studies Centre Working Paper Series No. 85 (2012). http://www.oxhip.org/publications/ humanitarian-innovation-and-refugee-protection-2/.

14. Ibid.

15. Horst, "Refugee Livelihoods"; Betts, Bloom, and Omata, "Humanitarian Innovation."

16. Sarah Dryden-Peterson, "Refugee Children Aspiring Toward the Future: Linking Education and Livelihoods," in Educating Children in Conflict Zones, ed. Karen Mundy and Sarah Dryden-Peterson (New York: Teacher's College Press, 2011).

17. Sarah Dryden-Peterson, "The Present Is Local, the Future Is Global? Reconciling Current and Future Livelihoods Strategies in the Education of Congolese Refugees in Uganda," Refugee Survey Quarterly 25, no. 2 (2006): 81-92.

18. Machtelt De Vriese, Refugee Livelihoods: A Review of the Evidence (Geneva: UNHCR, Evaluation and Policy Analysis Unit, 2006).

19. Barry Sesnan, Graham Wood, Marina L. Anselme, and Ann Avery, "Skills Training for Youth," Forced Migration Review 20 (2004); Dominic Odwa Atari, Samer Abdelnour, Kevin McKague, and Robert Wager, Technical Vocational and Entrepreneurial Capacities in Southern Sudan: Assessment and Opportunities (Toronto: Centre for Refugee Studies, York University, 2010).

20. Lynn Davies, "Can Education Interrupt Fragility? Toward the Resilient Citizen and the Adaptable State," in Educating Children in Conflict Zones: A Tribute to Jackie Kirk, ed. Karen Mundy and Sarah Dryden-Peterson (New York: Teacher's College Press, 2011), 36; G. Walker, J. Millar Wood, and E. Allemano, Liberia Youth Fragility Assessment (Washington, DC: USAID, 2009), ix.

21. I.e. basic education to relevant vocational training to career counselling/apprenticeships/microcredit.

22. Walker, Millar Wood, and Allemano, Liberia Youth.

23. Dryden-Peterson, "Refugee Children Aspiring"; Walker, Millar Wood, and Allemano, Liberia Youth.

24. I.e. “Technology Issue," Forced Migration Review 38 (2011), http://www.fmreview.org/technology; Melissa Beouy, Steven Ehrenberg, and Stephen Luke, "Technology (ICT) Strategies to Support Education: A Brief Analysis Report," Family Health International (FHI) 360 (2012); Jacqueline Strecker, "Refugee ICT Initiatives: Improving Practices for Refugee Participation" (Ottawa: International Development Research Centre, 2010).

25. Michael Brophy, "Open Learning and Distance Education for Displaced Populations," in The Open Classroom: Distance Learning In and Out of Schools, ed. Jo Bradley (London: Taylor and Francis, 2004).

26. See Strecker, "Refugee ICT Initiatives," for an expanded list of refugee ICT initiatives. 
27. Communication with UNHCR Livelihoods Unit staff, July 30, 2013; "Analysis: Refugees Aim for Self-Reliance, Not Hand-outs," IRIN News, 6 February 2013, http://www.irinnews.org/report/97418/ analysis-innovating-for-refugee-self-reliance.

28. Michael Trucano, "Worst Practice in ICT Use in Education," Edutech: A World Bank Blog on ICT Use in Education (30 April 2010), http://blogs.worldbank.org/edutech/worst -practice; see also Jacqueline Strecker, "Recommendations for CTA Kakuma Programming" (Ottawa: International Development Research Centre, 2010).

29. "Impact evaluation is the systematic identification of the effects-positive or negative, intended or not-on individual households, institutions, and the environment caused by a given development activity," quoted from Daniel A. Wagner, "Overview," in Monitoring and Evaluation of ICT in Education Projects: A Handbook for Developing Countries, ed. Daniel A. Wagner, Bob Day, Tina James, Robert B. Kozma, Jonathan Miller, and Tim Unwin (Information for Development Program 2005), http://www.infodev.org/articles/ monitoring-and-evaluation-ict-education-projects.

30. P. Duignan, "Approaches and Terminology in Programme and Policy Evaluation," in Evaluating Policy and Practice, ed. N. Lunt, C. Davidson, and K. McKegg (Auckland: Pearson Education, 2003).

31. Indeed, the evaluation notes that reliable statistical data on CTAs was largely unavailable, in part due to implementing partners' lack of capacity (AIR, "The Current State of UNHCR's Community Technology Access Program," 2).

32. Operational and fiscal autonomy refers to the point when the CTA program is fiscally independent and no longer requires annual funding injections; Duignan, "Approaches and Terminology in Programme and Policy Evaluation."

33. UNHCR, "Sub-Project Description," Annex A, 2012, in AIR, "The Current State of UNHCR's Community Technology Access Program."

34. AIR, "The Current State of UNHCR's Community Technology Access Program," I1.

35. Ibid., 7.

36. The evaluation report does not specify precisely how the data was analyzed.

37. AIR, "The Current State of UNHCR's Community Technology Access Program," 5-6.

38. International Covenant on Civil and Political Rights, 19 December 1966, 999 UNTS 171, Art. 19(2).

39. This activity is only an option in countries where CTAs are connected to the Internet (i.e. not in Bangladesh).

40. "CTA Impact Evaluation Mission Field Notes," American Institutes for Research (June 2012), 39, in possession of author.

41. "Community Technology Access," UNHCR website, accessed August 29, 2012, http://www.unhcr.org/ pages/4ad2e8286.html

42. International Covenant on Economic, Social and Cultural Rights, 16 December 1966, 993 UNTS 3, Art. 13.
43. AIR, "The Current State of UNHCR's Community Technology Access Program," 18.

44. Ibid., 14.

45. Ibid., 43 .

46. Ibid., 75 .

47. Ibid., 75 .

48. UNHCR, UNHCR Education Strategy, 2012-2016 (February 28, 2012), 38-39, http://www.unhcr.org/refworld/ $\mathrm{docid} / 4 \mathrm{f} 4 \mathrm{~cd} 9812 . \mathrm{html}$

49. Division of Operational Services, "Project Proposal," 13-15.

50. AIR, "The Current State of UNHCR's Community Technology Access Program," 78.

51. Ibid., 18.

52. UNHCR, Age, Gender and Diversity Policy (June 8, 2011), http://www.unhcr.org/refworld/docid/4def34f6887.html.

53. "CTA Impact Evaluation Mission Field Notes," 35.

54. Daniela Ionita, "Community Technology Access Project," Forced Migration Review 38 (2011), accessed 29 August 2012, http://www.fmreview.org/technology/ionita.html.

55. AIR, "The Current State of UNHCR's Community Technology Access Program," 74

56. Ibid., 91 .

57. Ibid., 88 .

58. UN High Commissioner for Refugees, "UNHCR Policy on Refugee Protection and Solutions in Urban Areas," (September 2009), para. 40, accessed August 29, 2012, http:// www.unhcr.org/refworld/docid/4ab8e7f72.html.

59. "CTA Impact Evaluation Mission Field Notes," 30.

60. AIR, "The Current State of UNHCR's Community Technology Access Program," 44.

61. Strecker, "Refugee ICT Initiative."

62. Naohiko Omata, "Online Connection for Remittances," Forced Migration Review 38 (2011), accessed 29 July 2013, http://www.fmreview.org/technology/omata.html.

63. AIR, "The Current State of UNHCR's Community Technology Access Program," 86.

64. "CTA Impact Evaluation Mission Field Notes," 40.

65. AIR, "The Current State of UNHCR's Community Technology Access Program," 30-31.

66. Walker, Millar Wood, and Allemano, Liberia Youth Fragility Assessment; Dryden-Peterson, "Refugee Children Aspiring."

67. Betts, Bloom, and Omata, "Humanitarian Innovation," 15.

68. Beouy, Ehrenberg, and Luke, "Technology (ICT) Strategies to Support Education"; Tim Unwin, "Towards a Framework for the Use of ICT in Teacher Training in Africa," Open Learning: The Journal of Open and Distance Education, 20, no. 2 (2005), 113-129.

69. AIR, "The Current State of UNHCR's Ccommunity Technology Access Program," 31.

70. Ibid., 66 .

71. Ibid., 28 .

72. Ibid., 20

73. Ibid., 30; Strecker, "Refugee ICT Initiatives."

74. AIR, "The Current State of UNHCR's Community Technology Access Program," 24. 
75. Communication with UNHCR Livelihoods Unit staff, 30 July 2013. [NB: These ideas for the strategy have yet to be fully developed and approved.]

76. For example, the establishment of UNHCR's Innovation Unit and its partnership with the Humanitarian Innovation Project indicate that CTAs and similar programs will be the focus of continued attention and improvement. See: https://www.facebook.com/UNHCRInnovate.

Jessica Anderson has a master's degree from the Glendon School of Public and International Affairs, York University, Toronto. She completed an internship in the Division of International Protection, UNHCR HQ, Geneva, in the summer of 2012. This report summarizes the 2012 CTA evaluation report (currently unpublished) and was written in collaboration with Terra MacKinnon, Audrey Nirrengarten, and Jacqueline Strecker (Education Unit), Daniela Ionita, Troy Etulain, and Line Pedersen (Livelihoods Unit), and Jeff Crisp (Policy Development and Evaluation Service). are credited and the original publication in Refuge: Canada's Journal on Refugees is cited. 
(C) Jessica Anderson, 2013. This open-access work is licensed under a Creative Commons Attribution-NonCommercial 4.0 International License, which permits use, reproduction and distribution in any medium for non-commercial purposes, provided the original author(s) are credited and the original publication in Refuge: Canada's Journal on Refugees is cited. 